\title{
Honeybee Pollen Extracts Reduce Oxidative Stress and Steatosis in Hepatic Cells
}

\author{
Juan Esteban Oyarzún ${ }^{1}$, Marcelo E. Andia ${ }^{1} \oplus$, Sergio Uribe ${ }^{1}$, Paula Núñez Pizarro ${ }^{2}$, Gabriel Núñez ${ }^{3}$, \\ Gloria Montenegro ${ }^{3}$ and Raquel Bridi ${ }^{2, *}$
}

1 Biomedical Imaging Center, School of Medicine, Pontificia Universidad Católica de Chile, ANID-Millennium Science Initiative Program-Millennium Nucleus for Cardiovascular Magnetic Resonance, Santiago 7820436, Chile; jeoyarzu@uc.cl (J.E.O.); meandia@uc.cl (M.E.A.); suribe@uc.cl (S.U.)

2 Departamento de Farmacia, Facultad de Química, Pontificia Universidad Católica de Chile, Avda Vicuña Mackenna 4860, Santiago 7820436, Chile; pjnunez@uc.cl

3 Departamento de Ciencias Vegetales, Facultad de Agronomía e Ingeniería Forestal, Pontificia Universidad Católica de Chile, Avda Vicuña Mackenna 4860, Santiago 7820436, Chile; ginunez@uc.cl (G.N.); gmonten@uc.cl (G.M.)

* Correspondence: rbridi@uc.cl; Tel.: +56-2-354-1580

Citation: Oyarzún, J.E.; Andia, M.E.; Uribe, S.; Núñez Pizarro, P.; Núñez, G.; Montenegro, G.; Bridi, R. Honeybee Pollen Extracts Reduce Oxidative Stress and Steatosis in Hepatic Cells. Molecules 2021, 26, 6. https:/ /dx.doi. org $/ 10.3390 /$ molecules 26010006

Academic Editors: Ryszard Amarowicz and Adriano Costa de Camargo

Received: 20 November 2020

Accepted: 15 December 2020

Published: 22 December 2020

Publisher's Note: MDPI stays neutral with regard to jurisdictional claims in published maps and institutional affiliations.

Copyright: () 2020 by the authors. Licensee MDPI, Basel, Switzerland. This article is an open access article distributed under the terms and conditions of the Creative Commons Attribution (CC BY) license (https: / / creativecommons.org/ licenses/by/4.0/).

\begin{abstract}
Nonalcoholic fatty liver disease (NAFLD) is a major cause of morbidity and mortality worldwide. Additional therapies using functional foods and dietary supplements have been investigated and used in clinical practice, showing them to be beneficial. Honeybee pollen from Chile has shown a large concentration of phenolic compounds and high antioxidant activity. In this work, we characterized twenty-eight bee pollen extracts from the central zone of Chile according to botanical origin, phenolic profile, quercetin concentration, and antioxidant activity (FRAP and ORAC-FL). Our results show a statistically significant positive correlation between total phenolic content and antioxidant capacity. Selected samples were evaluated on the ability to reverse the steatosis in an in vitro cell model using Hepa1-6 cells. The pollen extracts protected Hepa1-6 cells against oxidative damage triggered by 2,2'-azo-bis(2-amidinopropane) dihydrochloride (AAPH)derived free radicals. This effect can be credited to the ability of the phenolic compounds present in the extract to protect the liver cells from chemical-induced injury, which might be correlated to their free radical scavenging potential. Additionally, bee pollen extracts reduce lipid accumulation in a cellular model of steatosis. In summary, our results support the antioxidant, hepatoprotective, and anti-steatosis effect of bee pollen in an in vitro model.
\end{abstract}

Keywords: bee pollen; NAFLD; antioxidant; phenolic compounds; hepatoprotection

\section{Introduction}

Nonalcoholic fatty liver disease (NAFLD) is a multifactorial disease, related to a complex living environment, heredity, and dietary habits. Patients with NAFLD have lower survival rates than healthy people of the same age and gender [1]. High-calorie diets and continued inactivity contribute to weight gain and promote the development of NAFLD [2]. Although the early stages of NAFLD may be reversible, studies have shown that $15 \%$ to $20 \%$ of patients with NAFLD can develop cirrhosis, and $30 \%$ to $40 \%$ of patients can suffer liver disease-related morbidity and mortality [3]. Weight loss through improved diet and increased physical activity has been the cornerstone therapy of NAFLD. Recent therapies using functional foods and dietary supplements have been shown to be beneficial $[2,3]$. There is evidence of a link between oxidative stress and the presence of NAFLD and its progression, particularly related to mechanisms such as mitochondrial dysfunction, endoplasmic reticulum (ER) stress, iron metabolism derangements, insulin resistance, and endothelial dysfunction [4-6].

The understanding of the molecular mechanisms responsible for lipid accumulation, oxidative balance impairment, and fibrosis in the liver could improve the therapeutic 
approach to decrease the risk of the disease progression. Antioxidant compounds, which modulate lipogenesis, inflammation, lipid oxidation and peroxidation, represent a new, attractive therapeutic approach for patients suffering from hepatic steatosis [5,7]. International recommendations for the treatment of nonalcoholic fatty liver suggest a reduction in the consumption of fats and sugars in the diet [5]. Additionally, the use of antioxidant micronutrients has been suggested as a potential treatment alternative, since oxidative stress is also pivotal in the progression of NALFD [7]. The Mediterranean diet, which is rich in antioxidant compounds such as polyphenols [8,9], has been shown to have a protective effect against this disease. Polyphenols are a heterogeneous group of compounds derived from plants. The hepatoprotective effects of some polyphenols have been reported, which modulate insulin resistance, oxidative stress, and inflammation [9]. These researchers suggest that the hepatoprotector mechanism may be related to the enhancement of the antioxidant capacity of cells $[9,10]$.

Several groups have outlined the potential bioactive roles for honeybee pollen including antioxidant, immunomodulatory, cardioprotective, antimicrobial, and anti-inflammatory activities [11]. These activities are mainly attributed to phenolic compounds such as flavonoids. Poland bee pollen extract reduced and/or prevented the occurrence of steatosis and degenerative changes in the liver of mice caused by a high-fat diet, which may suggest a hepatoprotective role of bee pollen extract [12]. However, another study using Schisandra chinensis bee pollen on nonalcoholic fatty liver disease and gut microbiota in high-fat diet-induced obese mice suggested that phenolic compound present in the extract could attenuate the features of the metabolic syndrome [13].

In order to provide new and healthy sources of important food components, human society has developed so-called "functional food" which can be defined as a food prepared in order to afford different compounds (i.e., vitamins, fatty acids, proteins, carbohydrates, polyphenols, carotenoids, etc.) with the ability to have a positive influence on health [14]. The average content of polyphenols in pollen is around 1.6\% (1.6 g/100 g) [15], which defines it as an excellent source of these bioactive compounds [14]. The botanical origin of pollen, its chemical composition, the amounts of major bioactive compounds such as polyphenols and carotenoids, and its antioxidant properties should be provided to better understand the impact of pollen addition in the formulation of functional food and feed products [14].

The central zone of Chile is one of five regions in the world that has a Mediterranean climate and is the largest producer of bee pollen in the country. The Valparaiso region (V region) is located in this area, which is covered by native vegetation characterized by a high level of endemism and biodiversity. Beehives are usually located in the "matorral" (the scrubs) communities, shrubby sclerophyllous vegetation that covers the slopes of the coastal range in the semiarid Mediterranean zone [16]. Our preliminary studies about chemical composition of bee pollen from the central zone of Chile showed the strong presence of phenolic compounds such as syringic acid, coumaric acid, myricetin, and quercetin [16].

The purpose of this study was to characterize according to botanical origin, phenolic profile, quercetin concentration, and antioxidant activity the honeybee pollen extracts from the central zone of Chile. From the characterized honeybee pollen extracts we selected six pollen samples with different concentrations of total phenols and we tested their ability to reverse steatosis in an in vitro cell model of liver steatosis.

\section{Results and Discussion}

2.1. Botanical Origin, Content of Phenolic Compounds, Flavonoid Compounds, Quercetin Concentration, ORAC-PGR, and FRAP Values of Honeybee Pollen

Table 1 shows the three predominant plant species in the samples, average values of total phenols (TP), flavonoids content (FC), concentration of quercetin (HPLC-DAD), and antioxidant activity (FRAP and ORAC-FL) in bee pollen extracts (BPEs) from the $\mathrm{V}$ region of Chile collected in 2018. 
Table 1. Average values of total phenols (TP), flavonoids, FRAP, ORAC-FL, and quercetin (QE) concentration in bee pollen extracts from the V region of Chile collected in 2018.

\begin{tabular}{|c|c|c|c|c|c|c|c|c|}
\hline \multirow{2}{*}{ Samples } & \multicolumn{3}{|c|}{ Predominant Plant Species } & \multirow{2}{*}{$\begin{array}{c}\begin{array}{c}\text { Total } \\
\text { Phenols }\end{array} \\
\begin{array}{c}\text { (mg } \\
\text { GAE/100 g } \\
\text { Bee Pollen) }\end{array}\end{array}$} & \multirow{2}{*}{$\begin{array}{c}\text { Flavonoids } \\
\text { (mg QE/100 } \\
\text { g Bee } \\
\text { Pollen) }\end{array}$} & \multirow{2}{*}{$\begin{array}{c}\text { FRAP } \\
\begin{array}{c}(\mu \mathrm{mol} \text { TE } / \mathrm{g} \\
\text { Bee Pollen) }\end{array}\end{array}$} & \multirow{2}{*}{$\begin{array}{c}\text { ORAC-FL } \\
\begin{array}{c}(\mu \mathrm{mol} \text { TE/g } \\
\text { Bee Pollen) }\end{array}\end{array}$} & \multirow{2}{*}{ 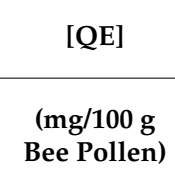 } \\
\hline & First & Second & Third & & & & & \\
\hline $1 *$ & $\begin{array}{l}\text { Eschscholzia } \\
\text { californica }\end{array}$ & Adesmia arborea & $\begin{array}{l}\text { Taraxacum } \\
\text { officinale }\end{array}$ & $1448 \pm 116$ & $252 \pm 18$ & $194 \pm 7$ & $492 \pm 25$ & $60.32 \pm 0.34$ \\
\hline 2 & $\begin{array}{c}\text { Eschscholzia } \\
\text { californica }\end{array}$ & Brassica rapa & $\begin{array}{l}\text { Eucalyptus } \\
\text { sp. }\end{array}$ & $1301 \pm 12$ & $504 \pm 21$ & $111 \pm 4$ & $312 \pm 22$ & $99.37 \pm 0.18$ \\
\hline $3 *$ & Brassica rapa & $\begin{array}{c}\text { Cryptocarya } \\
\text { alba }\end{array}$ & $\begin{array}{l}\text { Sophora } \\
\text { macrocarpa }\end{array}$ & $1141 \pm 30$ & $479 \pm 6$ & $74 \pm 1$ & $412 \pm 89$ & $98.70 \pm 18.45$ \\
\hline $4^{*}$ & Brassica rapa & $\begin{array}{c}\text { Cryptocarya } \\
\text { alba }\end{array}$ & $\begin{array}{l}\text { Anthemis } \\
\text { cotula }\end{array}$ & $954 \pm 83$ & $304 \pm 8$ & $78 \pm 15$ & $307 \pm 61$ & $66.99 \pm 2.82$ \\
\hline 5 & Brassica rapa & Adesmia arborea & $\begin{array}{l}\text { Colliguaja } \\
\text { odorifera }\end{array}$ & $920 \pm 38$ & $261 \pm 14$ & $101 \pm 1$ & $224 \pm 27$ & $16.04 \pm 0.08$ \\
\hline 6 & Acacia caven & $\begin{array}{l}\text { Eschscholzia } \\
\text { californica }\end{array}$ & Acacia caven & $848 \pm 2$ & $273 \pm 12$ & $70 \pm 4$ & $253 \pm 8$ & $84.22 \pm 20.77$ \\
\hline 7 & Brassica rapa & $\begin{array}{c}\text { Cryptocarya } \\
\text { alba }\end{array}$ & Azara sp. & $8379 \pm 55$ & $346 \pm 8$ & $76 \pm 15$ & $398 \pm 34$ & $65.13 \pm 0.76$ \\
\hline 8 & Brassica rapa & $\begin{array}{c}\text { Cryptocarya } \\
\text { alba }\end{array}$ & Azara sp. & $780 \pm 17$ & $326 \pm 20$ & $91 \pm 16$ & $397 \pm 40$ & $39.49 \pm 0.75$ \\
\hline 9 & Brassica rapa & $\begin{array}{c}\text { Colliguaja } \\
\text { odorifera }\end{array}$ & $\begin{array}{c}\text { Amomyrtus } \\
\text { luma }\end{array}$ & $767 \pm 22$ & $168 \pm 10$ & $86 \pm 4$ & $371 \pm 36$ & $133.68 \pm 1.10$ \\
\hline 10 & Brassica rapa & $\begin{array}{c}\text { Eschscholzia } \\
\text { californica }\end{array}$ & $\begin{array}{c}\text { Cryptocarya } \\
\text { alba }\end{array}$ & $767 \pm 109$ & $205 \pm 7$ & $107 \pm 6$ & $350 \pm 38$ & $4.55 \pm 0.52$ \\
\hline $11^{*}$ & Azara celastrina & Mix & $\begin{array}{c}\text { Cryptocarya } \\
\text { alba }\end{array}$ & $759 \pm 7$ & $331 \pm 26$ & $60 \pm 2$ & $183 \pm 11$ & $37.44 \pm 0.54$ \\
\hline 12 & $\begin{array}{c}\text { Cryptocarya } \\
\text { alba }\end{array}$ & Brassica rapa & $\begin{array}{c}\text { Eschscholzia } \\
\text { californica }\end{array}$ & $758 \pm 72$ & $251 \pm 12$ & $84 \pm 8$ & $282 \pm 68$ & $25.05 \pm 0.33$ \\
\hline 13 & Brassica rapa & $\begin{array}{c}\text { Colliguaja } \\
\text { odorifera }\end{array}$ & $\begin{array}{c}\text { Eschscholzia } \\
\text { californica }\end{array}$ & $744 \pm 15$ & $172 \pm 9$ & $96 \pm 9$ & $338 \pm 27$ & $175.22 \pm 0.96$ \\
\hline 14 & Brassica rapa & Adesmia arborea & $\begin{array}{c}\text { Cryptocarya } \\
\text { alba }\end{array}$ & $725 \pm 44$ & $337 \pm 14$ & $66 \pm 3$ & $197 \pm 35$ & $296.08 \pm 3.43$ \\
\hline 15 & Brassica rapa & Eucalyptus sp. & $\begin{array}{l}\text { Raphanus } \\
\text { sativus }\end{array}$ & $717 \pm 15$ & $149 \pm 16$ & $98 \pm 1$ & $371 \pm 45$ & $115.74 \pm 0.99$ \\
\hline 16 & Brassica rapa & $\begin{array}{c}\text { Cryptocarya } \\
\text { alba }\end{array}$ & $\begin{array}{c}\text { Hypochaeris } \\
\text { radicata }\end{array}$ & $715 \pm 52$ & $186 \pm 14$ & $80 \pm 17$ & $281 \pm 87$ & $162.38 \pm 0.51$ \\
\hline 17 & Brassica rapa & $\begin{array}{c}\text { Cryptocarya } \\
\text { alba }\end{array}$ & $\begin{array}{l}\text { Schinus } \\
\text { latifolius }\end{array}$ & $588 \pm 12$ & $150 \pm 8$ & $66 \pm 13$ & $203 \pm 39$ & $121.87 \pm 0.74$ \\
\hline 18 & $\begin{array}{c}\text { Eschscholzia } \\
\text { californica }\end{array}$ & Brassica rapa & $\begin{array}{l}\text { Schinus } \\
\text { latifolius }\end{array}$ & $580 \pm 5$ & $165 \pm 17$ & $56 \pm 3$ & $231 \pm 47$ & $145.98 \pm 1.18$ \\
\hline 19 & $\begin{array}{c}\text { Cryptocarya } \\
\text { alba }\end{array}$ & Brassica rapa & $\begin{array}{c}\text { Eschscholzia } \\
\text { californica }\end{array}$ & $540 \pm 21$ & $88 \pm 8$ & $61 \pm 4$ & $277 \pm 99$ & $409.94 \pm 1.79$ \\
\hline 20 & $\begin{array}{c}\text { Eschscholzia } \\
\text { californica }\end{array}$ & $\begin{array}{c}\text { Cryptocarya } \\
\text { alba }\end{array}$ & $\begin{array}{c}\text { Anthemis } \\
\text { cotula }\end{array}$ & $536 \pm 10$ & $260 \pm 6$ & $35 \pm 9$ & $277 \pm 129$ & $22.34 \pm 0.1$ \\
\hline 21 & Brassica rapa & $\begin{array}{c}\text { Lythrum } \\
\text { hyssopifolia }\end{array}$ & $\begin{array}{c}\text { Robinia } \\
\text { pseudoacacia }\end{array}$ & $518 \pm 51$ & $102 \pm 5$ & $54 \pm 7$ & $185 \pm 74$ & $63.19 \pm 0.36$ \\
\hline $22 *$ & Brassica rapa & $\begin{array}{l}\text { Eschscholzia } \\
\text { californica }\end{array}$ & Cactaceae & $368 \pm 19$ & $75 \pm 7$ & $51 \pm 2$ & $109 \pm 49$ & $6.59 \pm 0.19$ \\
\hline 23 & $\begin{array}{c}\text { Cryptocarya } \\
\text { alba }\end{array}$ & $\begin{array}{l}\text { Eschscholzia } \\
\text { californica }\end{array}$ & $\begin{array}{l}\text { Taraxacum } \\
\text { officinale }\end{array}$ & $364 \pm 14$ & $176 \pm 18$ & $38 \pm 6$ & $166 \pm 45$ & $11.2 \pm 0.14$ \\
\hline 24 & Brassica rapa & $\begin{array}{l}\text { Schinus } \\
\text { latifolius }\end{array}$ & $\begin{array}{l}\text { Azara } \\
\text { celastina }\end{array}$ & $350 \pm 41$ & $122 \pm 4$ & $41 \pm 3$ & $158 \pm 40$ & $5.24 \pm 0.45$ \\
\hline 25 & Brassica rapa & $\begin{array}{c}\text { Cryptocarya } \\
\text { alba }\end{array}$ & Azara sp. & $344 \pm 27$ & $128 \pm 6$ & $39 \pm 10$ & $191 \pm 28$ & $20.61 \pm 0.36$ \\
\hline 26 & $\begin{array}{c}\text { Cryptocarya } \\
\text { alba }\end{array}$ & $\begin{array}{c}\text { Eschscholzia } \\
\text { californica }\end{array}$ & Malva sp. & $315 \pm 15$ & $156 \pm 1$ & $27 \pm 2$ & $216 \pm 44$ & $4.29 \pm 0.45$ \\
\hline 27 & $\begin{array}{c}\text { Cryptocarya } \\
\text { alba }\end{array}$ & $\begin{array}{l}\text { Eschscholzia } \\
\text { californica }\end{array}$ & $\begin{array}{c}\text { Anthemis } \\
\text { cotula }\end{array}$ & $286 \pm 34$ & $153 \pm 3$ & $26 \pm 1$ & $242 \pm 42$ & $6.7 \pm 0.18$ \\
\hline $28 *$ & $\begin{array}{c}\text { Cryptocarya } \\
\text { alba }\end{array}$ & Anthemis cotula & $\begin{array}{l}\text { Baccharis } \\
\text { linearis }\end{array}$ & $102 \pm 20$ & $62 \pm 9$ & $19 \pm 2$ & $150 \pm 67$ & $15.08 \pm 0.3$ \\
\hline
\end{tabular}

* Select samples to carry out studies on the ability to reverse the steatosis and chemical characterization.

Botanical origin describes the presence of different plant sources used by bees to produce honeybee pollen. This description enables their classification as native/nonnative/mixed and monofloral/bifloral/multifloral bee pollen, according to the Chilean 
norm (NCh 3255, 2011) [17]. The majority of samples analyzed corresponded to nonnative multifloral followed by non-native monofloral and native monofloral. Among the non-native samples analyzed, the plant species Brassica rapa and Eschscholzia californica predominated. The predominant native species are Cryptocarya alba (peumo) and Acacia caven (espinillo). The complete information about botanical origin of the bee pollen samples performed by palynological analysis is shown in Supplementary Materials Table S1.

In Table 1 the samples are listed in order of their TP concentration, from highest to lowest. Sample 1 presents the highest value for TP $(1448 \pm 116 \mathrm{GAE} / 100 \mathrm{~g}$ of bee pollen) while sample 28 presents the lowest value (102 $\pm 20 \mathrm{mg}$ GAE $/ 100 \mathrm{~g}$ of bee pollen). The content of flavonoids (FC) ranged between $504 \pm 21$ (sample 2) and $62 \pm 9 \mathrm{mg}$ QE $/ 100 \mathrm{~g}$ (sample 28). The values of antioxidant capacity, evaluated by FRAP and ORAC-FL, were between $194 \pm 7$ (sample 1) and $19 \pm 2 \mu \mathrm{mol} \mathrm{TE} / \mathrm{g}$ bee pollen (sample 28), and between $492 \pm 25$ (sample 1) and $109 \pm 49 \mu \mathrm{mol} \mathrm{TE} / \mathrm{g}$ bee pollen (sample 22), respectively. The samples showed a considerable content of quercetin (HPLC-DAD) ranged from $409.94 \pm$ 1.79 (sample 19) to $4.29 \pm 0.45 \mathrm{mg} / 100 \mathrm{~g}$ fresh bee pollen (sample 26).

The analysis of the 28 honeybee pollen extracts shows that there is a statistically significant positive correlation between total phenolic content and ORAC-FL $\left(R^{2}=0.41\right.$; $p \leq 0.03)$, and between the flavonoid content and FRAP $\left(\mathrm{R}^{2}=0.40 ; p \leq 0.03\right)$, and ORAC-FL $\left(\mathrm{R}^{2}=0.50 ; p \leq 0.01\right)$. Nonetheless, no correlation was observed between the quercetin $(\mathrm{QE})$ concentration and antioxidant capacity (FRAP and ORAC-FL).

\subsection{Phenolic Acids of Honeybee Pollen Extracts (BPEs) Determined by HPLC-DAD}

From the results showed in the Table 1 , six bee pollen samples were selected according to their content of phenolic compounds, to create three categories: high, medium, and low phenolic compounds content. Those samples were evaluated on the ability to reverse the steatosis in an in vitro cell model using Hepa1-6 cells and the concentrations of the most representative phenols (cinnamic acids, flavonols, flavone, and flavanone) were determined by HPLC-DAD; the results are depicted in Table 2. Fourteen phenolic compounds were quantified, and five compounds were found in all samples (syringic acid, cinnamic acid, rutin, myricetin, and quercetin). These data corroborated our previous studies that showed a considerable content of not only quercetin but also myricetin [16].

Table 2. Phenolic acids and flavonoids of honeybee pollen extracts (BPE) determined by HPLC-DAD ${ }^{1}$.

\begin{tabular}{|c|c|c|c|c|c|c|c|}
\hline \multirow{2}{*}{ Samples } & \multicolumn{7}{|c|}{ mg Phenolic Acids/100 g Pollen } \\
\hline & Chlorogenic & Caffeic & Syringic & Coumaric & Sinapic & Ferulic & Cinnamic \\
\hline 1 & 0 & 0 & $6.62 \pm 0.05$ & $0.8 \pm 0.12$ & 0 & $6.76 \pm 0.57$ & $20.18 \pm 0.1$ \\
\hline 3 & 0 & 0 & $1.77 \pm 0.1$ & $0.94 \pm 0.02$ & 0 & $15.34 \pm 0.36$ & $16.14 \pm 0.21$ \\
\hline 4 & 0 & $0.93 \pm 0.02$ & $1.35 \pm 0.02$ & $0.41 \pm 0.23$ & $0.98 \pm 0.42$ & $6.38 \pm 0.33$ & $21.42 \pm 0.31$ \\
\hline 11 & $15.92 \pm 0.18$ & 0 & $13.64 \pm 0.13$ & 0 & $16.7 \pm 0.3$ & $20.2 \pm 0.29$ & $10.15 \pm 0.04$ \\
\hline 22 & $26.21 \pm 0.37$ & $5.67 \pm 0.08$ & $5.81 \pm 0.2$ & $0.2 \pm 0.01$ & $5.36 \pm 0.22$ & $1.03 \pm 0.51$ & $2.81 \pm 0.91$ \\
\hline 28 & $16.76 \pm 1.16$ & 0 & $2.21 \pm 0.4$ & 0 & $19.05 \pm 5.78$ & 0 & $5.42 \pm 0.23$ \\
\hline \multirow{2}{*}{ Samples } & \multicolumn{7}{|c|}{ mg Flavonoids/ $100 \mathrm{~g}$ Pollen } \\
\hline & Epicatechin & Rutin & Myricetin & Quercetin & Apigenin & Rhamnetin & Catechin \\
\hline 1 & $7.95 \pm 0.1$ & $13.98 \pm 0.07$ & $775.89 \pm 1.87$ & $60.32 \pm 0.34$ & $34.62 \pm 2.71$ & 0 & 0 \\
\hline 3 & 0 & $7.19 \pm 0.18$ & $185.65 \pm 1.43$ & $98.7 \pm 18.45$ & $767.24 \pm 83.92$ & 0 & 0 \\
\hline 4 & $38.42 \pm 0.14$ & $36.2 \pm 0.68$ & $121.41 \pm 3.31$ & $66.99 \pm 2.82$ & 0 & 0 & 0 \\
\hline 11 & $21.4 \pm 0.05$ & $74.25 \pm 2.93$ & $96.46 \pm 0.41$ & $37.44 \pm 0.54$ & $21.05 \pm 2.56$ & $13.35 \pm 2.88$ & $15.8 \pm 0.34$ \\
\hline 22 & 0 & $2.74 \pm 1.43$ & $28.51 \pm 0.95$ & $6.59 \pm 0.19$ & $13.09 \pm 0.06$ & 0 & 0 \\
\hline 28 & 0 & $17.57 \pm 0.4$ & $35.49 \pm 3.08$ & $15.08 \pm 0.3$ & $6.98 \pm 0.63$ & $80.37 \pm 3.19$ & $17.96 \pm 0.44$ \\
\hline
\end{tabular}

${ }^{1}$ Data are expressed as $\mathrm{mg} / 100 \mathrm{~g}$ fresh bee pollen and the values represent the means $\pm \operatorname{SD}(n=3)$.

For selected samples, the analysis shows that there is a statistically significant positive correlation between flavonoid content and quercetin $\left(R^{2}=0.94 ; p \leq 0.01\right)$ and myricetin concentration $\left(R^{2}=0.79 ; p \leq 0.05\right)$. Previous studies proposed to use quercetin and 
myricetin as a quality indicator for honeybee pollen from this region of Chile [15], which can be used as quality control criteria for functional ingredients.

\subsection{Cytotoxicity and Hepatoprotective Activity}

In order to test the cytotoxicity of the six bee pollen samples selected, cultures of Hepa1-6 cells received treatment with ethanol extracts of bee pollen samples 1, 3, 4, 11, 22 , and 28 at different concentrations $(0.1,1.0,10 \mathrm{mg} / \mathrm{mL})$. Besides these treatments, the experiment included a control group (untreated cells cultures), which was considered to present $100 \%$ cell viability. The viability of the cell cultures was determined as percentage of cell viability in relation to the control. The cytotoxicity was determined by Alamar blue of Hepa1-6 cells. The assays demonstrated that pollen extracts $4,11,22$, and 28, at $0.1 \mathrm{mg} / \mathrm{mL}$ did not generate effects on cytotoxicity on these cells. At concentrations of 1 and $10 \mathrm{mg} / \mathrm{mL}$, the cytotoxicity of the extracts increases (Figure 1). Accordingly, we used $0.1 \mathrm{mg} / \mathrm{mL}$ as a safe concentration for the hepatoprotective experiments.

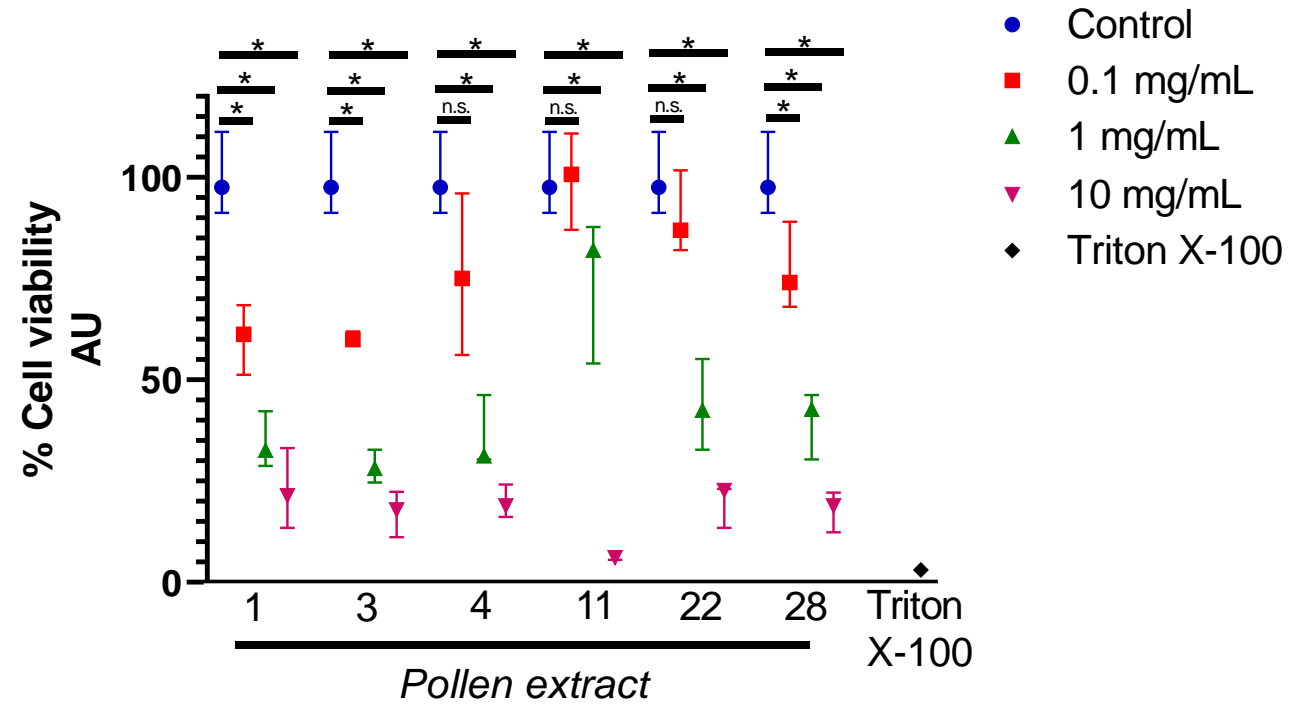

Figure 1. Maximum concentration of pollen extracts. Cell viability evaluated by Alamar blue of Hepa1-6 cells treated with ethanol extracts of pollen 1, 3, 4, 11, 22, and 28 at different concentration $(0.1,1,10 \mathrm{mg} / \mathrm{mL})$. Negative control, cells treated with TritonX-100 at $1 \%$ for $10 \mathrm{~min}$. Arbitrary Units (AU). Cell viability expressed as a percentage of viable cells relative to the control cells (untreated cells). Data are shown as median \pm first quartile and third quartile $(n=3)$. Mann-Whitney statistical test was performed between the control group and different pollen concentrations. The asterisks $\left(^{*}\right)$ represent statistically significant differences $(p<0.05)$. n.s.: not significant.

The hepatoprotective effect of the extracts of bee pollen was evaluated under the same conditions as the cytotoxicity assay. The oxidation of Hepa1-6 cells was induced by the potent oxidant $\mathrm{AAPH}$ and this oxidation was performed in the presence and absence of $0.1 \mathrm{mg} / \mathrm{mL}$ of each tested pollen extract. The results showed a significant increase in cell viability in the presence of pollen extracts $1,3,4,11$, and 28 when compare with AAPH treatment alone, suggesting the protective effects of those bee pollen extracts against oxidative stress AAPH-induced free radicals' accumulation in Hepa1-6 cells (Figure 2). 


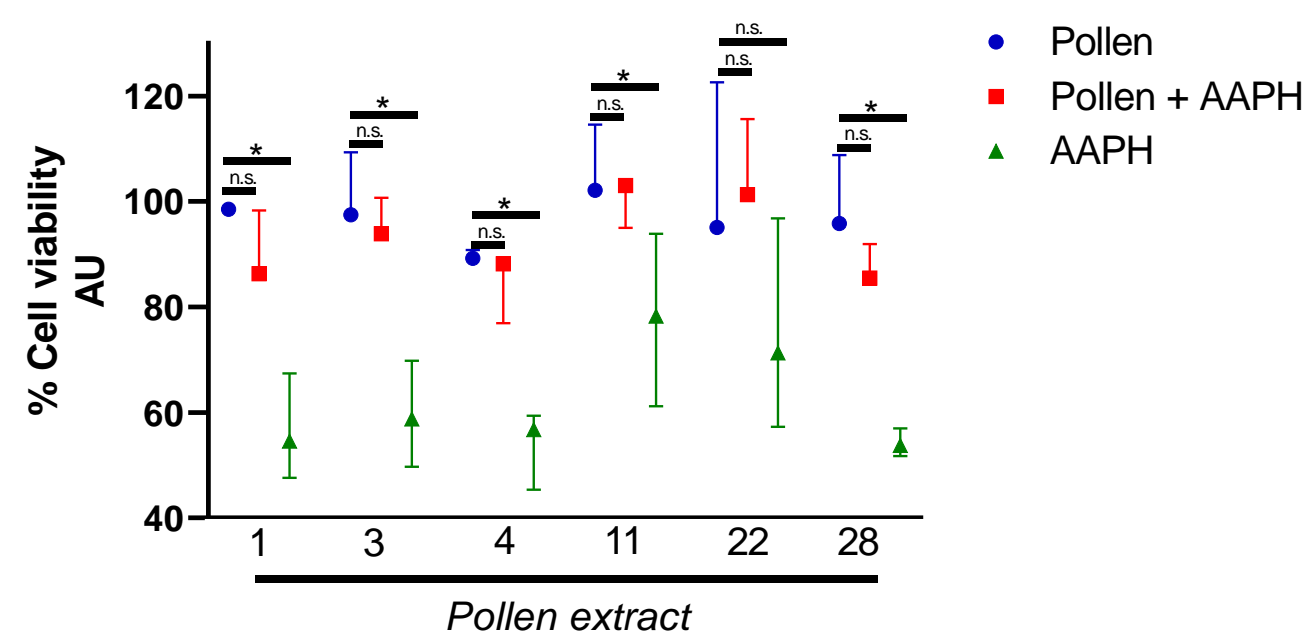

Figure 2. Pollen extract prevents 2,2'-Azobis(2-amidinopropane) dihydrochloride (AAPH) induced cell death. Cell viability evaluated by Alamar blue of Hepa1-6 cells treated with ethanol extracts of pollen $1,3,4,11,22$, and 28 at a concentration of $0.1 \mathrm{mg} / \mathrm{mL}$ and co-treatment with AAPH for $24 \mathrm{~h}$ at $0.2 \mathrm{~mm}$. Cell viability expressed as a percentage of viable cells relative to cells treated only with pollen extract. Data are shown as median \pm first quartile and third quartile $(n=3)$. Mann-Whitney statistical test was performed between the cells treated with pollen, pollen + AAPH, and AAPH. The asterisks $\left.{ }^{*}\right)$ represent statistically significant differences $(p<0.05)$. n.s.: not significant.

In order to test the potential effect of the pollen extracts in reversing steatosis, a classic steatosis cell model was used by loading Hepa1-6 cells with palmitic acid and oleic acid for $24 \mathrm{~h}[18,19]$. When we loaded the hepa1-6 cells with lipids for $24 \mathrm{~h}$ they showed increases in the bodipy mark (Figure 3). Interestingly, when these cells were loaded with lipids and cotreated with different pollen extract, it was possible to observe a significant decrease in the accumulation of lipids in comparison with the control cells (Figure 3).

A
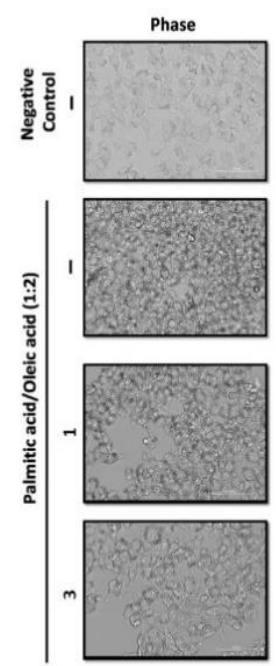
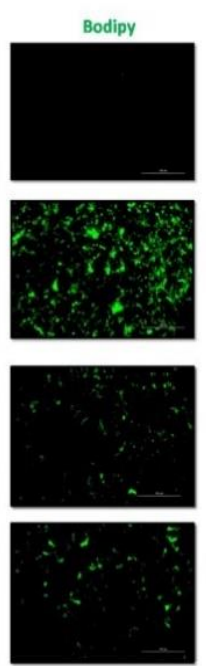
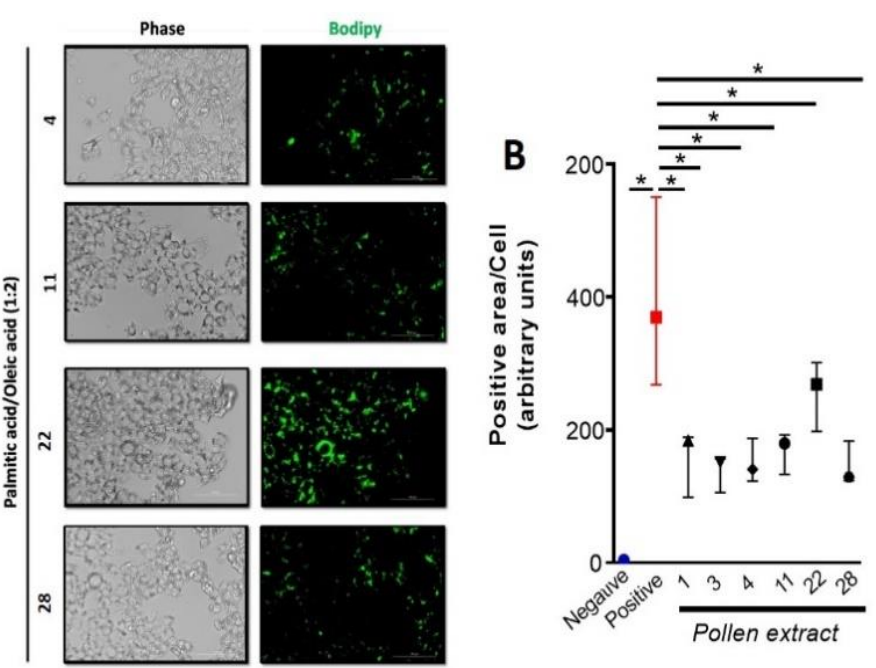

Figure 3. Pollen extracts reduce steatosis in an in vitro cell model. (A) Bodipy lipid staining in Hepa1-6 cells line treated

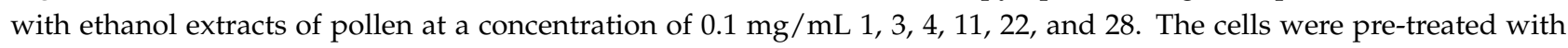
pollen extracts for $2 \mathrm{~h}$, prior to loading with lipids (palmitic/oleic acid) for an additional $24 \mathrm{~h}$. (B) The quantifications are in arbitrary units to estimate the bodipy lipid staining in Hepa1-6 line treated with ethanol extracts of pollen. Data are shown as median \pm first quartile and third quartile $(n=3)$. Mann-Whitney statistical test was performed between the positive control and different pollen extract. The asterisks $\left(^{*}\right)$ represent statistically significant differences $(p<0.05)$. 
It is possible to observe in the Figure 2 that the pollen extracts 1, 3, 4, 11, and 28 at a concentration $0.1 \mathrm{mg} / \mathrm{mL}$ showed a significant hepatoprotective effect against the oxidative damage caused by the free radical generator AAPH and these same pollen samples showed the best results in reducing the accumulation of lipids (Figure 3). We evaluated the correlation among the hepatoprotective effects of each pollen extracts and their total phenolic content, flavonoid content, quercetin concentration, and antioxidant capacity. The results indicated that there is a low positive correlation between steatosis reduction of total phenolic content $(\varrho=0.26)$, flavonoid content $(\varrho=0.23)$, and FRAP $(\varrho=$ 0.12 ). The antioxidant capacity (ORAC-FL) and quercetin concentration showed a moderate positive correlation with reduced steatosis, respectively $\varrho=0.49$ and 0.64 (Figure 4). The positive correlation between quercetin concentration and reduction of steatosis is a very interesting result since quercetin is present in all Chilean bee pollen samples studied in this and previous studies [16], corroborating the idea that this flavonoid is a good marker for determining the quality of Chilean honeybee pollen.
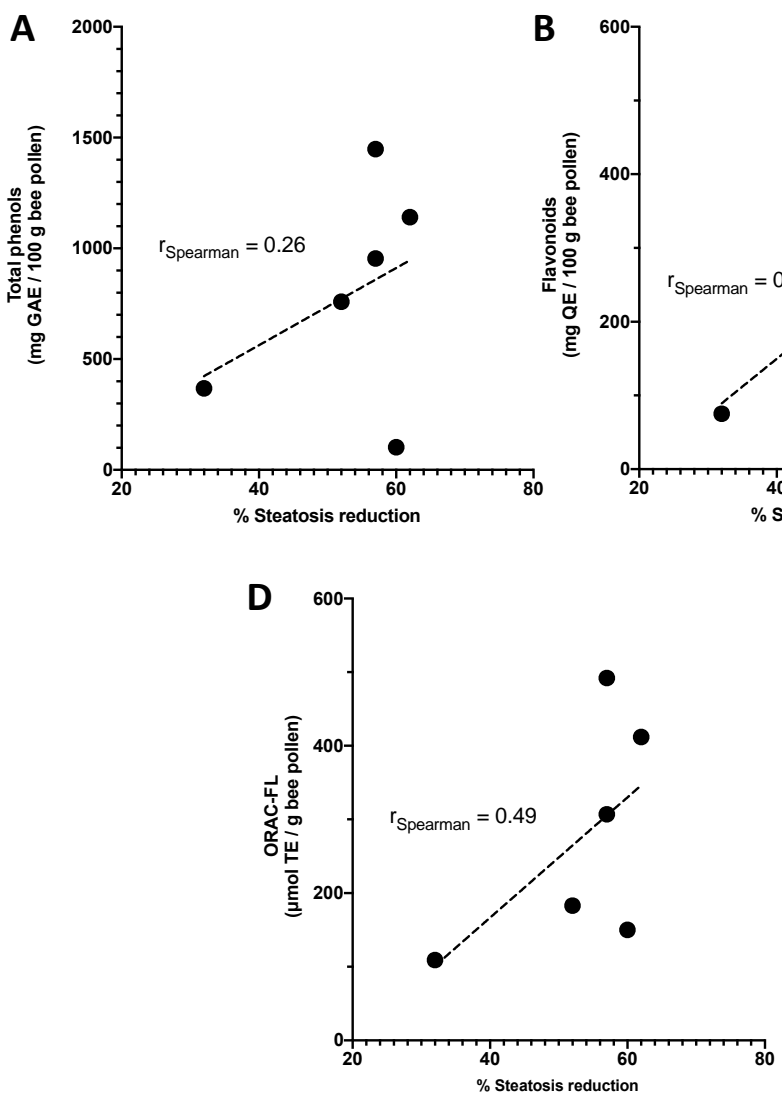
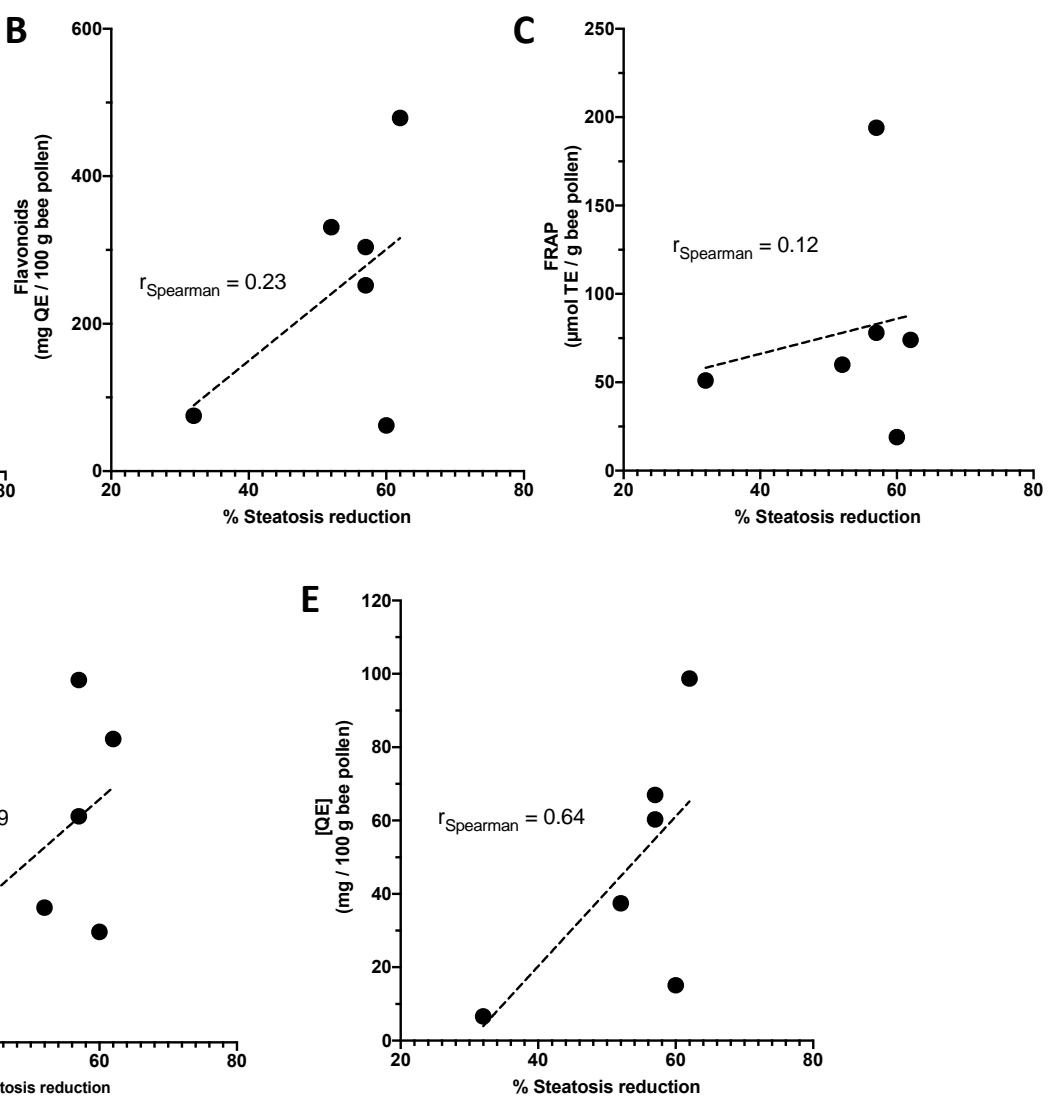

Figure 4. Correlation coefficient $(\varrho)$ from Spearman correlation analysis between hepatoprotective effects and (A) total phenols content, (B) flavonoid content, (C) antioxidant capacity (FRAP), (D) antioxidant capacity (ORAC-FL), and (E) quercetin concentration $[\mathrm{QE}]$.

Antioxidants that can inhibit free radical generation are important in terms of protecting the liver from chemical-induced damage by stabilizing the antioxidant systems in the cell. In vivo and in vitro studies have demonstrated the promising preventative and therapeutic effects of plant phenolics in a range of liver diseases, particularly in NAFLD [10]. Flavonoids are able to control de novo lipogenesis, inhibiting lipogenic proteins and increasing lipolytic proteins, and they are also effective scavengers of reactive species that are elevated in pathological states and metabolic disorders such as NAFLD. Recent studies have shown the beneficial effects of quercetin. In HepG2 cells and in animal models, an increase in mitochondrial biogenesis was observed [5]. Epicatechin and apigenin have been reported to protect the liver from NAFLD, which are associated with their effects on 
insulin resistance and for signaling the way to anti-inflammation as well as antioxidant action $[20,21]$. Dihydromyricetin supplementation improves glucose and lipid metabolism as well as various biochemical parameters in patients with nonalcoholic fatty liver disease, and the therapeutic effects of dihydromyricetin are likely attributable to improved insulin resistance and decreases in the serum levels of tumor necrosis factor-alpha, cytokeratin-18, and fibroblast growth factor 21 [20,22]. Furthermore, myricetin, a similar flavonoid that is in a higher concentration in our samples, between 35 and $775 \mathrm{mg} / 100 \mathrm{~g}$ pollen, can efficiently relieve hepatocyte necrosis, inflammation and oxidative stress, and in vitro studies have suggested that remarkably attenuated $\mathrm{H}_{2} \mathrm{O}_{2}$-triggered hepatotoxicity and ROS generation [23].

In conclusion, bee pollen extracts showed hepatoprotection against a known free radical generator such as AAPH, suggesting that the antioxidant potential of pollen is protecting against this insult. On the other hand, bee pollen extracts reduce lipid accumulation in a cellular model of steatosis. Those positive effects were positive correlated with the pollen's quercetin concentration. Our results highlight the potential use of bee pollen as a hepatoprotective and anti-steatosis treatment in fatty liver diseases and could be a potential micronutrient to prevent and eventually reverse NAFLD, which affects a large proportion of Western countries' populations. There is a worldwide prevalence of $25.24 \%$, with a higher percentage in the Middle East and South America, and a lower prevalence in Africa [24].

\section{Materials and Methods}

\subsection{Honeybee Pollen Samples}

Twenty-eight samples from the V region of Chile (GPS coordinate $33^{\circ} 3^{\prime} 47^{\prime \prime} \mathrm{S}, 71^{\circ} 38^{\prime} 22^{\prime \prime}$ $\mathrm{W})$ were provided as vacuum packed when fresh and frozen at $-20^{\circ} \mathrm{C}$ by associated beekeepers. The samples were collected during the dry seasons of 2018. The determination of botanical origin was performed using the palynological analysis method described in Chilean Regulation (NCh3255, 2011) [16]. To determine botanical origin, specific literature $[25,26]$ and the botanical bee pollen catalog at the Laboratory of Botany (Department of Plant Sciences, Faculty of Agronomy and Forest Engineering, Pontificia Universidad Católica de Chile, Santiago, Chile) were consulted.

\subsection{Extract Preparation and Phenolic Characterization}

The honeybee pollen extracts (BPEs) was obtained by ultrasonic extraction (Elmasonic $\mathrm{S} 10 \mathrm{H}$ ELMA) bath at $37 \mathrm{kHz}$ frequency and $240 \mathrm{~W}$ using one gram of fresh honeybee pollen in analytical grade absolute ethanol $(10 \mathrm{~mL})$ at room temperature $\left(25^{\circ} \mathrm{C}\right)$ for $10 \mathrm{~min}$ [27]. The mixture was centrifuged at $3130 \times g$ for 5 min and filtered using Whatman No. 1 paper. This procedure was repeated three times for each sample, and the collected extracts were combined to a final volume of $50 \mathrm{~mL}(1 \mathrm{~g} / 50 \mathrm{~mL})$. BPEs were stored at $-80^{\circ} \mathrm{C}$ in the dark until use.

The total polyphenols content in the extracts was measured using the Folin Ciocalteu's method. The gallic acid equivalents (GAE) were used to express the content of total polyphenols, i.e., milligrams per $100 \mathrm{~g}$ of bee pollen (mg GAE/100 g) [16]. The flavonoid content measured by $\mathrm{AlCl}_{3}$ method was calculated as milligrams of quercetin equivalents (QE) per $100 \mathrm{~g}$ of bee pollen (mg QE/100 g) [16].

\subsection{Antioxidant Capacity Assay}

The ferric reducing antioxidant power (FRAP) of the pollen extracts was determined as previously described by Bridi et al. [16]. The working FRAP solution was prepared daily by mixing 10 parts of acetate buffer (0.3 M pH 3.6), 1 part of $10 \mathrm{mM}$ TPTZ (2,4,6-tri(2-pyridyls-triazine, Sigma), and 1 part of $20 \mathrm{mM}$ ferric chloride. Aliquots of $270 \mu \mathrm{L}$ FRAP solution were mixed with $30 \mu \mathrm{L}$ of diluted BPE (1:100). The reaction mixtures were incubated for $30 \mathrm{~min}$ at $37^{\circ} \mathrm{C}$ and the absorbance was measured at $594 \mathrm{~nm}$ using a Cytation 5 multi-mode microplate reader from BioTek Instruments, Inc. (Winooski, VT, USA). As positive controls, 
ethanol solutions and Trolox $(5-30 \mu \mathrm{M})$ were used. The results are expressed as $\mu \mathrm{mol}$ Trolox equivalents per $\mathrm{g}$ of bee pollen $(\mu \mathrm{mol} \mathrm{TE} / \mathrm{g})$. Values are reported as mean $\pm \mathrm{SD}$ of 3 independent determinations.

The antioxidant capacity of BPEs was measured by using the ORAC-fluorescein (ORAC-FL) assay conducted on the basis of a report by Ou et al. [28] and adapted to the use of a fluorescent microplate reader (Cytation ${ }^{\mathrm{TM}} 5$ from BioTek Instruments Inc.) [16]. The fluorescein consumption was assessed by the decrease in fluorescence intensity of the sample (excitation: $493 \mathrm{~nm}$; emission $515 \mathrm{~nm}$ ). AAPH was used as the peroxyl generator and $\mu \mathrm{M}$ Trolox as a standard $(2-10 \mu \mathrm{M})$. The results are expressed as $\mu \mathrm{mol}$ Trolox equivalents per $100 \mathrm{~g}$ of bee pollen ( $\mu \mathrm{mol} \mathrm{TE} / 100 \mathrm{~g})$. Values are reported as mean $\pm \mathrm{SD}$ of 3 independent determinations.

\subsection{HPLC-DAD Analysis}

BPE samples were analyzed with a Hitachi Chromaster 5000 series high-performance liquid chromatography (HPLC) instrument equipped with an autosampler and a photodiode array detector (DAD) (Hitachi, Tokyo, Japan). The HPLC system was controlled by Chromaster system manager V1.2. The BPEs were separated using a mobile phase mixture of (A) methanol, (B) acetonitrile, and (C) $0.1 \%$ aqueous formic acid. The composition of the mobile phase mixture varied by employing the following HPLC stepwise gradient program: $0-10 \min 20 \%$ B, 80\% C; $10.1-40 \min 7.5 \%$ A, 25\% B 67.5\% C; $40.1-50$ min 15\% A, 25\% B, 60\% C; 50.1-65 min 15\% A, 45\% B 40\% C, and returned to starting conditions during the following $15 \mathrm{~min}$. The column used was a $250 \mathrm{~mm} \times 4.6 \mathrm{~mm}$ i.d., Purospher STAR RP-18 endcapped with a guard column of the same type while the flow rate was kept at $0.8 \mathrm{~mL} / \mathrm{min}$ and oven column set at $35^{\circ} \mathrm{C}$. The absorbance of $10 \mu \mathrm{L}$ eluate was monitored with a DAD detector set in the $210-550 \mathrm{~nm}$ range and the chromatograms were integrated for all standards and BPE samples at $290 \mathrm{~nm}$. Quantification was performed with calibration curves using commercially available standards (range 5-250 $\mu \mathrm{M}$ of each component). All analysis was performed in triplicate for standards and BPE samples [16].

\subsection{Cytotoxicity and Hepatoprotective Activity In Vitro}

Cell line: Hepa1-6 cells were used [29,30]. These cells were grown in $75 \mathrm{~cm}^{2}$ flasks using DMEM with high glucose content, supplemented with 10\% FBS (fetal bovine serum) and $1 \%$ antibiotic solution. The cells were kept in a humidified atmosphere with $5 \%$ $\mathrm{CO}_{2}-95 \%$ air at $37^{\circ} \mathrm{C}$.

Cytotoxicity and hepatoprotective activity: Hepa1-6 cells were seeded at a density of 50,000 cells per well in 96-well plates. After $24 \mathrm{~h}$, cells were incubated with ethanol and ethanol extracts of pollen $(1,3,4,11,22$, and 28) at different concentrations $(0.1,1,10 \mathrm{mg} / \mathrm{mL})$. The induction of cell damage was carried out using 2,2'-Azobis (2-amidinopropane) dihydrochloride (AAPH, $0.2 \mathrm{mM}$ ). Triton X100 1\% was applied as a positive control. Cell mortality was determined by reduction of resazurin (Alamar blue assay) and measuring fluorescence (560 nm excitation/590 nm emission) using a Cytation 5 multi-mode microplate reader from BioTek Instruments Inc. (Winooski, VT, USA) [31]. The results are expressed as a percentage of the control conditions of three independent experiments and four replicates per experiment.

\subsection{Statistical Analysis}

All data represent the mean values \pm SD of at least 3 independent experiments, each conducted in triplicate. Pearson and Spearman correlation and analyses were carried out using Origin Pro 8 software (MA, US). Statistical comparisons between groups were evaluated with one-way ANOVA followed by Tukey post-hoc test. In the in vitro experiment, the Mann-Whitney statistical test was performed. A value of $p<0.05$ was considered to be significant. 
Supplementary Materials: The following are available online, Table S1: Botanical origin and classification of bee pollen samples. Data are represented as the percentage of participation of each species in the total sample, according to weight of grams of pollen loads.

Author Contributions: J.E.O., G.N. and P.N.P. carried out the experimental work. S.U., M.E.A., G.M., and R.B. designed, supervised the work and prepared the manuscript. All authors have read and agreed to the published version of the manuscript.

Funding: This research received no external funding.

Data Availability Statement: Samples of the compounds are not available from the authors.

Acknowledgments: The authors gratefully acknowledge support from the associated companies Badani \& Guevara Ltd.a and Andes NutraClinic, and financial support from FIA (PYT-2018-0315), Fondequip EQM160042, ANID-Millennium Science Initiative Program CN17_129 and FONDECYT 1180525.

Conflicts of Interest: The authors declare no conflict of interest.

\section{References}

1. Adams, L.A.; Harmsen, S.; St Sauver, J.L.; Charatcharoenwitthaya, P.; Enders, F.B.; Therneau, T.; Angulo, P. Nonalcoholic fatty liver disease increases risk of death among patients with diabetes: A community-based cohort study. Am. J. Gastroenterol. 2010, 105, 1567-1573. [CrossRef] [PubMed]

2. Liu, B.; Zhang, J.; Sun, P.; Yi, R.; Han, X.; Zhao, X. Raw Bowl Tea (Tuocha) Polyphenol Prevention of Nonalcoholic Fatty Liver Disease by Regulating Intestinal Function in Mice. Biomolecules 2019, 9, 435. [CrossRef] [PubMed]

3. Schwenger, K.J.P.; Allard, J.P. Clinical approaches to non-alcoholic fatty liver disease. World J. Gastroenterol. 2014, $20,1712-1723$. [CrossRef] [PubMed]

4. Masarone, M.; Rosato, V.; Dallio, M.; Gravina, A.G.; Aglitti, A.; Loguercio, C.; Federico, A.; Persico, M. Role of Oxidative Stress in Pathophysiology of Nonalcoholic Fatty Liver Disease. Oxid Med. Cell Longev. 2018, 2018, 9547613. [CrossRef] [PubMed]

5. Ferramosca, A.; Di Giacomo, M.; Zara, V. Antioxidant dietary approach in treatment of fatty liver: New insights and updates. World J. Gastroenterol. 2017, 23, 4146-4157. [CrossRef]

6. Sun, X.; Seidman, J.S.; Zhao, P.; Troutman, T.D.; Spann, N.J.; Que, X.; Zhou, F.; Liao, Z.; Pasillas, M.; Yang, X.; et al. Neutralization of Oxidized Phospholipids Ameliorates Non-alcoholic Steatohepatitis. Cell Metab. 2020, 31, 189-206.e8. [CrossRef]

7. Kitade, H.; Chen, G.; Ni, Y.; Ota, T. Nonalcoholic Fatty Liver Disease and Insulin Resistance: New Insights and Potential New Treatments. Nutrients 2017, 9, 387. [CrossRef]

8. Shahidi, F.; Ambigaipalan, P. Phenolics and polyphenolics in foods, beverages and spices: Antioxidant activity and health effects-A review. J. Funct. Foods 2015, 18, 820-897. [CrossRef]

9. Zhang, P.Y. Polyphenols in Health and Disease. Cell Biochem. Biophys. 2015, 73, 649-664. [CrossRef]

10. Li, S.; Tan, H.-Y.; Wang, N.; Zhang, Z.-J.; Lao, L.; Wong, C.-W.; Feng, Y. The Role of Oxidative Stress and Antioxidants in Liver Diseases. Int. J. Mol. Sci. 2015, 16, 26087-26124. [CrossRef]

11. Li, Q.; Wang, K.; Marcucci, M.; Christine, A.; Sawaya, H.; Hu, L.; Xue, X.; Wu, L.-M.; Hu, F.-L. Nutrient-rich bee pollen: A treasure trove of active natural metabolites. J. Funct. Foods 2018, 49, 472. [CrossRef]

12. Rzepecka-Stojko, A.; Kabała-Dzik, A.; Kubina, R.; Jasik, K.; Kajor, M.; Wrześniok, D.; Stojko, J. Protective Effect of Polyphenol-Rich Extract from Bee Pollen in a High-Fat Diet. Molecules 2018, 23, 805. [CrossRef] [PubMed]

13. Cheng, N.; Chen, S.; Liu, X.; Zhao, H.; Cao, W. Impact of SchisandraChinensis Bee Pollen on Nonalcoholic Fatty Liver Disease and Gut Microbiota in HighFat Diet Induced Obese Mice. Nutrients 2019, 11, 346. [CrossRef] [PubMed]

14. Kostić, A.Ž.; Milinčić, D.D.; Barać, M.B.; Ali Shariati, M.; Tešić, Ž.L.; Pešić, M.B. The Application of Pollen as a Functional Food and Feed Ingredient-The Present and Perspectives. Biomolecules 2020, 10, 84.

15. Komosinska-Vassev, K.; Olczyk, P.; Kaźmierczak, J.; Mencner, L.; Olczyk, K. Bee Pollen: Chemical Composition and Therapeutic Application. Evid. Based Complement. Altern. Med. eCAM 2015, 2015, 1-6. [CrossRef]

16. Bridi, R.; Atala, E.; Pizarro, P.N.; Montenegro, G. Honeybee Pollen Load: Phenolic Composition and Antimicrobial Activity and Antioxidant Capacity. J. Nat. Prod. 2019, 82, 559-565. [CrossRef]

17. Montenegro, G.; Gómez, M.; Díaz-Forestier, J.; Pizarro, R. Aplicación de la Norma Chilena Oficial de denominación de origen botánico de la miel para la caracterización de la producción apícola. Cienc. Investig. Agrar. 2008, 35, 181-190. [CrossRef]

18. Levy, G.; Cohen, M.; Nahmias, Y. In Vitro Cell Culture Models of Hepatic Steatosis. Methods Mol. Biol. 2015, 1250, 377-390.

19. Alkhatatbeh, M.J.; Lincz, L.F.; Thorne, R.F. Low simvastatin concentrations reduce oleic acid-induced steatosis in HepG(2) cells: An in vitro model of non-alcoholic fatty liver disease. Exp. Ther. Med. 2016, 11, 1487-1492. [CrossRef]

20. Saha, P.; Talukdar, A.D.; Nath, R.; Sarker, S.D.; Nahar, L.; Sahu, J.; Choudhury, M.D. Role of Natural Phenolics in Hepatoprotection: A Mechanistic Review and Analysis of Regulatory Network of Associated Genes. Front. Pharmacol. 2019, 10, 509. [CrossRef]

21. Sen, S.; Chakraborty, R. Chapter 19-Herbs, Gastrointestinal Protection, and Oxidative Stress. In Gastrointestinal Tissue; GraciaSancho, J., Salvadó, J., Eds.; Academic Press: Cambridge, MA, USA, 2017; pp. 259-274. 
22. Chen, S.; Zhao, X.; Wan, J.; Ran, L.; Qin, Y.; Wang, X.; Gao, Y.; Shu, F.; Zhang, Y.; Liu, P.; et al. Dihydromyricetin improves glucose and lipid metabolism and exerts anti-inflammatory effects in nonalcoholic fatty liver disease: A randomized controlled trial. Pharmacol Res. 2015, 99, 74-81. [CrossRef] [PubMed]

23. Lv, H.; An, B.; Yu, Q.; Cao, Y.; Liu, Y.; Li, S. The hepatoprotective effect of myricetin against lipopolysaccharide and Dgalactosamine-induced fulminant hepatitis. Int. J. Biol. Macromol. 2020, 155, 1092-1104. [CrossRef] [PubMed]

24. Younossi, Z.M.; Koenig, A.B.; Abdelatif, D.; Fazel, Y.; Henry, L.; Wymer, M. Global epidemiology of nonalcoholic fatty liver disease-Meta-analytic assessment of prevalence, incidence, and outcomes. Hepatology 2016, 64, 73-84. [CrossRef] [PubMed]

25. Heusser, C.J.; Moar, N.T. Pollen and spores of Chile: Modern types of the Pteridophyta, Gymnospermae, and Angiospermae. N. Z. J. Bot. 1973, 11, 389-391. [CrossRef]

26. Marticorena, C. Contribución a la estadística de la flora vascular de Chile. Gayana Bot 1990, 47, 8.

27. Rodriguez-Gonzalez, I.; Ortega-Toro, R.; Díaz-Moreno, A. Influence of microwave- and ultrasound-assisted extraction on bioactive compounds from pollen. Contemp. Eng. Sci. 2018, 11, 1669-1676. [CrossRef]

28. Ou, B.; Hampsch-Woodill, M.; Prior, R.L. Development and Validation of an Improved Oxygen Radical Absorbance Capacity Assay Using Fluorescein as the Fluorescent Probe. J. Agric. Food Chem. 2001, 49, 4619-4626. [CrossRef]

29. Madanayake, T.W.; Fidler, T.P.; Fresquez, T.M.; Bajaj, N.; Rowland, A.M. Cytochrome P450 2 S1 depletion enhances cell proliferation and migration in bronchial epithelial cells, in part, through modulation of prostaglandin E(2) synthesis. Drug Metab. Dispos. 2012, 40, 2119-2125. [CrossRef]

30. Rampersad, S.N. Multiple applications of Alamar Blue as an indicator of metabolic function and cellular health in cell viability bioassays. Sensors 2012, 12, 12347-12360. [CrossRef]

31. Riss, T.L.; Moravec, R.A. Use of multiple assay endpoints to investigate the effects of incubation time, dose of toxin, and plating density in cell-based cytotoxicity assays. Assay Drug Dev. Technol. 2004, 2, 51-62. [CrossRef] 